\title{
The Economic Impact of Renewable Energy Development in Indonesia
}

\author{
Fathul Nugroho ${ }^{1}$, Noor Syaifudin², \\ ${ }^{1}$ The Future Institute, Dukuh Patra V No.48, Kuningan, Jakarta, Indonesia \\ ${ }^{2} U W A$ Business School, Business School Building, Crawley Campus The University of Western \\ Australia 35 Stirling Highway Crawley WA 6009 Perth, Australia \\ ${ }^{3}$ Fiscal Policy Agency, Ministry of Finance of Republic of Indonesia, \\ Notohamiprodjo Building, 1st Floor, Jl. Wahidin No 1, Senen, Jakarta, 10710, Indonesia
}

\begin{abstract}
Renewable energy is believed to play a greater role in addressing climate change, economic development, and energy sustainability. Energy efficiency and renewable energy are similar with two sides of the same coin, that is, cannot be split. Currently, most of the developed countries are implementing energy efficiency while promoting renewable energy sources and technologies at the same time. It is wellknown that renewable energy is one of the solutions for the sustainability of global energy system. Efforts to improve the share of renewable energy in transportation, industrial, and power generation sectors have been implemented in some countries. More countries in the world adopt renewable energy as alternative sources of energy in order to improve country's energy efficiency. Indeed, however, the studies that deeply analyze the linkage between renewable energy and energy efficiency, as well as its economic impact, are still limited. Thus, this study attempts to find this linkage.
\end{abstract}

Keywords: economic impact; renewable energy; GDP

\section{Introduction}

Currently, most of the developed countries are implementing energy efficiency while promoting renewable energy sources and technologies at the same time. The European Union
(EU) Commission, for instance, has set an ambitious target to improve its energy efficiency by $15 \%$ and adopt renewable energy by $20 \%$ by 2020 with $10 \%$ biofuels target. In addition, The European Parliament even proposed a higher target of renewable energy

*Corresponding author's email: soib2007@gmail.com

ISSN: 2549-3221 (Print) 2549-323X (Online)

DOI: $10.26487 /$ hebr.v\%vi\%i.1243 
adoption, which is $25 \%$ by 2020 . Many scholars and institutions have supported EU's target, because they argued that by implementing energy efficiency plans and adopting renewable energy, EU can reduce the dependence on fossil fuels as much as $20 \%$ as well as tackle down climate change by a $20 \%$ reduction of greenhouse gas emissions.

\begin{tabular}{|ll|}
\hline \multicolumn{2}{l|}{ Nomenclature } \\
APBN $\quad$ Anggaran Pendapatan \\
dan Belanja Negara/ State Budget \\
GHG $\quad$ Green House Gas \\
GDP $\quad$ Gross Domestic Product \\
MoE $\quad$ Ministry of Environment \\
MEMR Ministry of Energy and \\
Mineral Resources \\
EIA Energy \\
Administration \\
\hline
\end{tabular}

Currently, some major European countries such as Denmark, Sweden, Finland, and Austria have adopted a high share of renewable energy. These countries have adopted renewable energy as much as $17.0 \%, 39.8 \%, 28.5 \%$, and $23.3 \%$ respectively from its total energy consumption. However, the UK sets a target of only $15 \%$ renewable energy improvement due to its current adoption of renewable energy, which is far below other European countries, which is only $1.5 \%$.

Power generation is one of the prospective sectors which can adopt high renewable energy sources in the short term to facilitate the mitigation of climate change. If the world could adopt at least $20 \%$ of renewable energy by 2020 similar to what $\mathrm{EU}$ has been targeting, this mitigation action is expected to reduce the impact of climate change in the future. By increasing the share of renewable energy to fulfil the current energy consumption, the world would be able to deal with the increasing energy demand. Abulfotuh [1] argues that if there is a change in energy sources portfolio by increasing the share of renewable energy, the environmental risk caused by fossil fuels emission can be reduced.

It is well-known that renewable energy is one of the solutions for the sustainability of global energy system. Efforts to improve the share of renewable energy in transportation, industrial, and power generation sectors have been implemented in some countries. For instance, Brazil has been successful in changing its portfolio of energy sources by adopting a large amount of renewable energy. In 2000, the share of renewable energy among Brazil's total energy supplies such as biofuels from sugarcane derivatives and biomass accounted for about $16 \%$ of total energy consumed. The consumption of biomass has been declining in the last few years and has been replaced by biofuels from sugarcane products. The total share of renewable energy to Brazil's energy sources portfolio has accounted for about $56 \%$ as of 2000. This is a very high renewable energy fraction for a middle-income developing nation [2].

The United Nations (UN) has long been encouraged thedevelopmentofrenewable energy sources and technologies in order to deal with climate change and energy sustainability issue. Intergovernmental Panel on Climate Change (IPCC), a panel under UN, in 2007 recommended more energy efficiency implementation and renewable energy adoption in order to reduce the current level of $\mathrm{CO}_{2}$ emission and thus contribute to the mitigation of climate change. Stern [3] also argues that the adoption of renewable energy and technologies is one of the solutions to mitigate the climate change.

The EU experiences and strategies in implementing renewable energy are valuable to be customized by other countries. They have enacted several 
policies to promote further development of renewable energy as an alternative to future energy. More than 65 countries now have national goals for accelerating the use of renewable energy and enacting far-reaching policies to meet those goals. Policies to promote renewable energy have mushroomed in recent years. At least 60 countries have some policy to promote renewable power generation. The most common policy is the feed-in law. By 2007, at least 37 countries and nine states/provinces had adopted feedin policies, more than half of which have been enacted since 2002 [4].

The EU Commission and Parliament have set an operational target for each EU member. By 2010, each EU member is required to achieve $7 \%$ share of renewable energy in power generation sector. However, each individual country is allowed to set their target but not less than $7 \%$. The UK for example has set a $10 \%$ as its target, but indeed this target is too high for the UK and it appears unlikely to meet this target. In 2007, the UK's renewable energy share in power generation was only 4.96 percent. One of the main impediments of the UK in achieving this target is that the renewable energy power generators were unable to access the power grids. Therefore, learning from the UK's experience, the GOI should promote integrated policies including the market arrangements.

\section{Objectives}

This study aims to provide an analysis of the contribution of renewable energy to improving Indonesia's energy efficiency. Furthermore, this study aims to analyze whether renewable energy will improve Indonesia's economy as the literature reviews have suggested.

\section{Method}

\subsection{Overview of Indonesia Energy Sector}

There are three major concerns regarding Indonesia's energy sector. First, recently, Indonesia is facing the problem of security supply of oil. Currently, People are concerned whether the government can guarantee supply for daily national consumption. In 2003, Indonesian oil consumption already exceeded its production. This excessive demand for oil is being threatened by the national energy security. Second, the increasing demand for oil means more budgets are needed to subsidize oil imports. The GOI stated that the current ability of its budget to fund subsidies is very limited. Third, there has been a decreasing trend towards energy efficiency in Indonesia. This study will mainly discuss to the third problem of Indonesia's energy sector since the topic of this study is on the energy efficiency issue. However, this study also discusses the first two problems of Indonesia's energy sector problem in order to provide the big picture regarding Indonesia's energy sector.

\subsubsection{The Depletion of Indonesia's Oil Production}

Referring to the current national oil consumption and production level, Indonesia's oil production has been decreasing since 2003. Meanwhile, Indonesia is currently facing high increases of average per capita oil consumption; the annual rate is around $0.05 \%$. In 2005, the per capita oil consumption is 19.85 litres per month, it had increased from 19.51 litres in 2004, and the trend is still increasing. In addition, the population of Indonesia is growing with annual growth estimated at $2 \%$ per year. Hence, Indonesia's future oil consumption will increase. However, 
the increase in oil consumption is not followed by a rapid increase of new invention of oil reserves both onshore and offshore. As a result, in 2003, Indonesia is no longer a net oil exporter, since the oil consumption exceeded the oil production, thus, currently Indonesia is a net oil importer.

Fig. 1. Indonesia's oil production and consumption in $1980-2005$

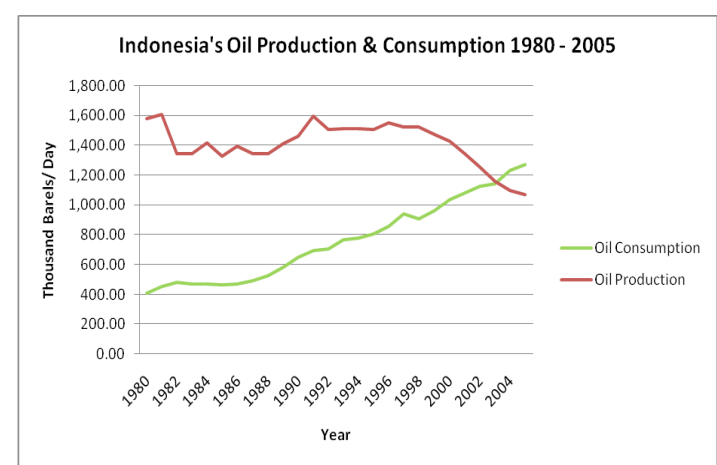

In 2005, some of Indonesia's largest oil production fields were already overexploited and its production capacity has been declining. While many other oil exploration projects are in progress, however, up to now, these projects have not carried out adequate new oil resources on-stream to cover the diminishing volume of production at some older fields [5]. The World Oil (2005) estimated that Indonesia's proven oil reserves are 5.03 billion barrels, while BP Statistical Review (2005) estimated that Indonesia has only 4.7 billion barrels proven oil reserve. In addition, Oil and Gas Journal estimated that proven oil reserves in Indonesia have declined to 4.3 billion barrels (see Table 1. below).

Table 1. Comparison of Indonesia's potential oil reserves according to different sources

\begin{tabular}{lll}
\hline $\begin{array}{l}\text { Oil } \\
\text { (Billion Barrels) }\end{array}$ & Oil & Oil \\
(Billion Barrels) & (Billion Barrels) \\
\hline BP Statistical Review & World Oil & Oil \& Gas Journal \\
Year-End 2005 & Year-End 2005 & January 1, 2007 \\
4.700 & 5.025 & 4.300 \\
\hline
\end{tabular}

Two problems cause a slow rate in inventing new oil field in Indonesia. First is the high oil production cost in Indonesia. The government's project financial watchdog (BPKP) said it is due to markup practices in cost recovery that has been causing high oil production cost in Indonesia. Oil production cost in Indonesia is around US\$9 a barrel compared to only US\$3.50 in Malaysia. This high-cost recovery has prevented some major oil producers in Indonesia from exploring other potential oil fields. Second, the price control over gasoline prices by the government. This would prevent prices to reach its normal level. The increases of price in economic terms mean economic incentive to conserve from the consumer perspective, but more incentive to produce from the producer point of view. On the other hand, low price of fossil fuels will force the level of consumption to higher level. Therefore, since the government set such a price ceiling to some types of gasoline, the oil producers in Indonesia lack the incentives to expand their production.

\subsubsection{The Security of Oil Supply}

The oil and gas industry has an important role in Indonesia's economy; it is having been a major contributor to Indonesia's state budget. International Petroleum Monthly ranked Indonesia as the 2oth oil producer in terms of its capacity with $1.4 \%$ of international market share, while Indonesia's gas production was ranked 9th globally with $2.7 \%$ market share [5]. Therefore, since Indonesia's oil production capacity is decreasing, the contribution of oil revenue to GDP is decreasing as well. This problem has not only affected the government's budget, but it also became a security issue regarding the scarcity of oil supply. In 2006 and beginning of 2007, the government had failed to 
retain the oil supply in some regions in Indonesia, and it emerged a scarcity of oil stock, and the people have to wait for several hours to buy oil. In addition, since the price of oil is fluctuating, and even in October 2008 the price of oil has hit a new record at $\$ 147$ per barrel, the price of oil has been affecting the capacity of the government budget to subsidize oil imports, thus, affecting the domestic oil supply.

\subsubsection{Budget Constraint: Cost for Oil Subsidies}

Indonesia has long been retaining subsidies for domestic gasoline prices including gasoline and diesel prices, and the fuels are retailed at a lower rate from the global market prices. In the past few years, the government has announced a series of subsidies withdrawal that resulted in modest rises in petroleum prices. In September 2005, the GOI significantly cut oil subsidies; and as a result, petroleum prices rose by an average $125 \%$. Despite a threat to its budget, the GOI still maintained subsidies for oil and electricity, which are Rp 68.6 trillion for oil and $\mathrm{Rp} 25.8$ trillion for electrics in the national budget 2007, which was almost 14 percent of the total national budget. This high budget allocation for oil and electricity subsidies from the government have not yet shifted to renewable energy sources to substitute the use of petroleum.

Furthermore, the government should pay attention to the increasing rate of oil consumption, since it will increase the cost of oil subsidies and thus threaten the government's budget. Therefore, it is important to anticipate an increase in the budget of oil and electricity subsidies, because huge amounts of subsidies will result in the increases in Indonesia's current account deficit. In 2006, the government pegged the price of oil in its budget statement at $\$ 57$ US dollar per barrel. However, by the fall in 2006, the world price of oil was above $\$ 70$ per barrel. As such, the government should allocate more budgets for subsidies that resulted in the increases in Indonesia's current account deficit.

\subsection{Data}

The raw data on GDP, gross fixed capital formation, total labor force, fossil fuel import, and energy use of Indonesia 1980-2005 are obtained from World Development Indicators [6] with total number of observations being 26 (the GDP, gross fixed capital formation, and fossil fuel import are in constant 2000 US\$). The energy use data comprises of fossil fuel energy consumption, combustible renewable and waste consumption, and clean energy consumption (all data are in terms $\mathrm{kg}$ of oil equivalent). The energy efficiency data is calculated by dividing GDP over total energy consumption for each year. For other statistical data such as energy intensity, petroleum, coal, natural gas, and renewable energy consumption, the data were collected from International Energy Annual Report 2006 published by Energy Information Agency (EIA).

By definition, combustible renewable and waste comprise of solid biomass and animal products, gas/liquids from biomass, industrial waste and municipal waste. Biomass is defined as any plant matter used directly as fuel or converted into fuels or electricity and/or heat. Some examples are wood, vegetal waste (including wood waste and crops used for energy production), ethanol, animal materials/wastes and sulphite lyes (Sulphite lyes are also known as "black liquor" and are an alkaline spent liquor from the digesters in the production of sulphate or soda pulp during the manufacture of paper. The energy 
content derives from the lignin removed from the wood pulp). Municipal waste comprises of wastes produced by the residential, commercial and public service sectors that are collected by local authorities for disposal in a central location for the production of heat and/or power. Hospital waste is included in this category [7]. Meanwhile, clean energy is a little harder to define. However, the common definition provides by the Government of Canada is any form of energy that causes little or no harm to the environment. Wind energy, solar energy, geothermal, photovoltaic, hydrogen, fuel cells, wave, and tidal energy are the common forms of clean energy that also renewable energy.

The capital stock is obtained by calculating the GDP and capital formation data using the following formula:

$$
K t=K t-1(1-\delta)+I t
$$

Where Kt is the capital stock in the current year; Kt-1, the capital stock in the previous year; $\delta$ is depreciation rate of capital stock, and It is a capital formation in the current year.

The initial value of capital stock is calculated using the following formula:

$$
K 1980=(I 1980 /(0.052+\delta)
$$

The depreciation rate is set at $6 \%$ as suggested by many relevant kinds of literature. The constant value of 0.052 is the coefficient or slope value of natural logarithm (Ln) gross fixed capital formation trend-line. The capital stock data is already in constant 2000 US\$.

\subsection{Impact of Renewable Energy on GDP}

The analysis in this section also employs the regression analysis. The objective of the analysis is to validate the contribution of renewable energy to improving the GDP of Indonesia.
As mentioned before, the simplest definition of energy efficiency is the ratio of GDP over total primary energy supply. Therefore, if the relationship between renewable energy and GDP is positive, it means that renewable energy contributes to the improvement of GDP. In other words, the share of renewable energy among total energy supply will improve the GDP of Indonesia and thus improve Indonesia's energy efficiency.

Domac et all. [8] recommend that the share of renewable energy improve the nation's energy efficiency through two mechanisms: (1) The establishment of renewable energy industries will generate a new business field and create new employment, thus promote further economic growth. (2) The adoption of renewable energy will change a country's energy consumption portfolio. For a country with high dependence on fossil fuels import, the adoption of renewable energy will shift the trade balance due to the substitution of energy. As a result, the overall trade balance will increase and thus improve the GDP. Therefore, this study aims to verify whether the contribution of renewable energy on GDP is positive.

The economic theory that supports the analysis in this section is the Keynesian model. It is well-known that basic Keynesian approach defines GDP as aggregate expenditure. This theory breaks the GDP into four components of spending on final goods and services, that is, consumer expenditure or simply consumption (C), investment (I), government expenditures (G), and net export (NX) or equal to exports minus imports. This theory is mathematically expressed by the following equation:

$$
G D P=C+I+G+(X-M),
$$

The substitution of primary energy with locally-produced renewable energy will reduce the total energy imports. As 
a result, it will contribute to the overall trade balance, since the Keynesian model trade balance is exports minus imports. This is in line with the theory proposed by Domac et all. [8] which recommended that the use of renewable energy will increase the trade balance.

Based on the theory above, this study constructs the regression equations. The analysis in this section employs logistic regression analysis model to measure the relationship of renewable energy and GDP. All data in this section are obtained from WDI online database. The regression equations are as follow:

\section{First model:}

$L n G D P=\beta O+\beta 1 L n H C+\beta 2 L n C F+$ $\beta 3 L n G E+\beta 4 T B+\beta 5 L n R E$

\section{Second model:}

$L n G D P=\beta o+\beta 1 L n H C+\beta 2 L n C F$ $+\beta 3 L n G E+\beta 4 T B+\beta 5 L n R E+\beta 6 L n$ FFI (11)

Where GDP gross domestic products, $\boldsymbol{H C}$ households consumption, $\boldsymbol{C F}$ capital formation, $\boldsymbol{G E}$ government expenditures, $\boldsymbol{T B}$ trade balance, $\boldsymbol{R E}$ renewable energy consumption, FFI fossil fuels imports.

The renewable energy indicators by an economy are collected from Renewables
Information (International Energy Agency [9] published by IEA since 2002. Data on household consumption, capital formation, trade balance, energy imports, and GDP are collected from the World Development Indicators database.

\section{Result and Findings}

This section presents the results of the regression analysis and its interpretations.

The regression analysis results of model 1 show that it has Adjusted R Square values of 0.993 , it means that the degree of fit of the equation is quite robust. In other words, the equation could explain the relationship between the variables. The F-test provides a hypothesis test of the overall fit of the expected equation. The F-statistic value of model 1 is 746.723 and statistically significant at 1 percent level.

Results of model 1 show that all variables are statistically significant and the signs are as expected, which means that the results in agreement with the theory. Renewable energy variable in this result does significantly affect GDP. The coefficient of renewable energy is 0.343 and statistically significant at $5 \%$ level. It is worth nothing, but for every increase

\begin{tabular}{lll}
\hline $\begin{array}{l}\text { Dependent Variable: GDP } \\
\text { Regressor }\end{array}$ & Model 1 & Model 2 \\
\hline Intercept & $-3.194^{*}(1.660)$ & $-3.819^{* * *}(1.393)$ \\
Ln HC (households consumption) & $0.263^{* * * *}(0.071)$ & $0.304^{* * * *}(0.060)$ \\
Ln CF (capital formation) & $0.227^{* * * *}(0.053)$ & $0.162^{* * * *}(0.049)$ \\
Ln GE (government expenditures) & $0.238^{* *}(0.098)$ & $0.307^{* * *}(0.084)$ \\
Ln TB (trade balance) & $0.113^{* *}(0.050)$ & $0.158^{* * *}(0.044)$ \\
Ln RE (renewable energy consumption) & $0.343^{* *}(0.140)$ & $0.314^{* *}(0.116)$ \\
Ln FFI (fossil fuels imports) & & $-0.038^{* * *}(0.012)$ \\
Summary Statistics & & \\
Adjusted R2 & 0.993 & 0.997 \\
F-statistic & $746.723^{* * *}$ & $902.986^{* * *}$ \\
DW-statistic & 1.096 & 1.807
\end{tabular}

Remark: Standard errors are given in parentheses under the coefficients. The individual coefficient and F-statistic are statistically significant at the ${ }^{*} 10 \%,{ }^{* *} 5 \%,{ }^{* * *} 1 \%$ significant level using a one-sided test. 
of $1 \%$ of renewable energy share among total primary energy supply, the GDP will be improved by 0.343 percent by holding other variables constant. The results also indicate that trade balance positively influences GDP with coefficient 0.113 and statistically significant at 5\% level. It means that for every increase of the volume of trade balance by $1 \%$, the GDP will be improved by 0.113 percent, holding other variables constant. In addition, the Pearson Correlation indicator shows that renewable energy and trade balance has a goodness fit of 0.934 and statistically significant at $1 \%$ level, which means that renewable energy does strongly influence trade balance.

In model 2, we included fossil fuel import in the equation, as Domac et all. [8] suggest that domestic-produced renewable energy will substitute the use of fossil fuels energy and thus reduce a number of energy imports. The regression findings in this model indicate that renewable energy variable has a positive sign, which means renewable energy has a positive correlation with GDP. The coefficient of renewable energy is 0.314 and statistically significant at $5 \%$ level. That is, for every increase the share of renewable energy by $1 \%$, the GDP will be improved by 0.314 percent, holding other variables constant. The trade balance and fossil fuels imports are also statistically significant at 1\% level. Fossil fuels variable, in this case, has a negative sign with coefficient 0.038 ; it means that every increase energy imports by $1 \%$, the GDP will be reduced by 0.038 percent, holding other variables constant.

The Pearson Correlation indicator shows that renewable energy has strong influences to GDP, trade balance, and fossil fuels imports. The goodness fit values of those variables are 0.980 , 0.934 , and 0.710 respectively and statistically significant at $1 \%$ level. In addition, the regression analysis results of model 2 show that it has Adjusted R Square values of 0.997 which mean that the degree of fit of this model has been improved. In other words, the equation can explain the relationship between the variables. The F-statistic value of model 2 is 902.986 and statistically significant at 1 percent level.

\section{Transition to Renewable Energy}

Deffeyes [10] and Campbell \& Laherrere [11] estimate that global oil production will reach its peak in the first decade of the twenty-first century. While it is very difficult to estimate exactly how long fossil fuels will last, the effort to shift to new energy sources should be taken. Referring to depletable resources model, oil and natural gas would be used until the marginal cost of further use exceeds the marginal cost of substitute resources, either more abundant depletable resources such as coal or renewable energy sources. Inefficient market path, the transition to these alternative sources would be smooth and harmonious whether or not the allocation of current energy sources is enough [12]

Facing a decreasing trend of energy efficiency, the Government of Indonesia through its Ministry of Energy and Mineral Resourcesshould takeimmediate action to tackle this issue. This due to improving energy efficiency of energy use is a key solution to improving energy security, improve industry profitability and competitiveness, and reduce the overall energy sector impacts on climate change [13].

Furthermore, in recent years, the climate change issue should be taken into consideration by policymakers around the globe including Indonesia in designing its energy policy, since the impact of climate change is global. The GOI should contribute to the effort of fighting climate change. The policy in 
the energy sector that transform the use of fossil fuels as the main energy sources to renewable energy source would be the part of the global action in fighting climate change.

The analysis in this study verifies that adopting renewable energy is an effective method to improve Indonesia's energy efficiency. Hence, this study recommends the MEMR to further promote renewable energy as the solution for energy efficiency problem and alternative source of energy. Practically, the MEMR should promote an integrated policy by which national planning on energy efficiency improvement and renewable energy development can be put into practice. The shift to renewable energy will improve energy efficiency on one side and reduce the dependence on oil as a main energy source on the other. The policy to further promote renewable energy will be in line with government program on energy diversification, which is one of the strategic steps to reduce the dependence of oil in the future. Through energy diversification program, Indonesia is expected to be able to provide cheaper and cleaner energy. As a result, it will reduce the budget for oil subsidies and improve the security supply of energy.

The strategy to shift from oil to renewable energy is not an impossible mission. Currently, Indonesia has a great potential for renewable energy. There are abundant resources of renewable energy such as geothermal, biofuels, water, biomass, wind, and solar energy. The current status of those potential resources is still underdeveloped, indeed, but renewable energy could play a greater role in energy diversification. Renewable energy is well-known as clean energy, which causes little or even no harm to the environment. Most of the renewable energy forms are low emission energy, even geothermal, water, wind, and solar energy is almost free from $\mathrm{CO} 2$ emissions. Given the fact that renewable energy in Indonesia is available in a large amount of potential reserves and low carbon emissions, renewable energy is expected to be a solution for long-term national energy sustainability.

Indonesia should learn from the $\mathrm{EU}$ which has set a high target to promote renewable energy by $20-25 \%$ by 2020 , and Brazil which has recently adopted renewable energy by $56 \%$. The GOI has set a relatively high target to increase the share of renewable energy in total energy supply. In the current Energy Blueprint, the GOI states its target to increase the share of renewable energy among total energy supply by at least $15 \%$ by 2025 . However, the current development of renewable energy is still facing some obstacles that can impede the government to achieve its target, namely, the current government subsidies on gasoline and electricity, natural gas and electricity prices ceiling, and an investment climate that still unfriendly to the investors.

Therefore, the development of renewable energy needs to be supported with integrated policies and strategy. With the strong regulatory framework, the government will be able to provide a certainty to the sustainability of the ongoing and future renewable energy development projects. In addition, the government should provide such incentives and subsidies to the institutions and firms that promote and employ renewable energy sources and technologies so that they can cover its marginal cost. Hence, in order to provide the framework for renewable energy development in Indonesia, the next section will discuss the broad range policy alternatives that can be considered by the MEMR. 


\section{The Current Renewable Energy Development and Potential}

\subsection{Geothermal Energy}

As a country located on the ring of the fire zone, Indonesia has a large amount of available geothermal energy resources. The ring of fire is a line where many volcanoes are located on, and it passes about 20\% of Indonesia's territory. Geothermal energy sources come from the less active volcanoes. However, as energy resources, geothermal has some limitations that are challenging to be solved. First, geothermal energy is commonly used for generating electricity, but since the heat from the geothermal sources cannot be transported to other sites that are far away from the heat sources, so it requires an electrical power plant to be installed on-site. Second, from an economic point of view, the development of geothermal power plant requires a high investment of capital, although once the power plant is installed, its variable and marginal cost are relatively low.

According to the state-owned oil company, PT. Pertamina [14], Indonesia's potential geothermal energy capacity is about 27,000 MW, which represents about one-third of the world's geothermal resources. About 50 percent of geothermal potential is located in Java and Bali. The geological surveys that have been conducted by PT. Pertamina on 214 locations proves that the total potential reserves are about 2,245 MW and the total probable proven reserves are 7,165 MW. Given this potential, the government of Indonesia could maximize geothermal energy sources utilization by installing power plants on those potential sites.

The current installed capacity of all geothermal power plants is about 964 MW or $3.6 \%$ of the total geothermal potential. The existing power plants are mainly located in Java - Bali Islands and only a few of it is located on Java Island. Some of the existing power plants are Gunung Salak (330 MW), Darajat (150 MW), Kamojang (140 MW), Wayang Windu (110 MW), Dieng (6o MW), Sibayak (20 MW), Lahendong (20 MW), and one in Sumatra Island that only $20 \mathrm{MW}$. The current geothermal development is regulated under the Law number 27, the year 2003 on Geothermal and Governmental Regulation No. 59/2007 on Geothermal Development.

For the future development of renewable energy, the Government of Indonesia targeted geothermal as one of the main energy sources for electricity. Referring to the Energy Blueprint, the GOI has set targets to install $6000 \mathrm{MW}$ by 2020 and increase to 9500 MW by 2025. The government appears to be very committed to the development geothermal energy sector as can be seen from the number of investments made in recent years. The government has invested a large amount of money to develop potential geothermal sites. In 2005, the GOI investment was around US\$ 65 million but rose rapidly to US\$ 181 million in 2006.

With its huge potential, geothermal energy is projected to become a prospective solution for Indonesia electricity sector problem. The current development progress is already on the track. However, the future plans should be supported by the strong regulatory framework and more attractive investment incentives in both geothermal sub-sector and electricity sector. The current electricity sector should be deregulated in order to allow private generators to enter the electricity market. Some incentives such as tax provisions for new investments can be provided to stimulate more investors. 


\subsection{Biofuels Energy}

The development of biofuels energy in Indonesia is growing rapidly. The government seriously supports the development of biofuels by establishing National Team for Biofuels Development as mandated by Presidential Decree No. 10/2006, the Coordinating Ministers of Economy and People's Welfare is the Co-Chairman of this team. The missions of this team are to compile national blueprint and roadmap to further developing bio-fuels at the national level, to assist the local government to create economic of scales of biofuels projects, to analyze the socio-economic and environmental impacts of biofuels production, and to create the regulatory framework for biofuels production and distribution.

Currently, the government is allowing PT. Pertamina to sell biodiesel from its gas stations, with biodiesel ratio $10 \%$ of diesel fuel. This practice is regulated under Ministerial Decree No. 3675K/24/ $\mathrm{DJM} / 2006$ that requires the producer to meet the specification and quality of biodiesel standard SNI 04-7182-2006 that are equal to EU and US standards ASTM D 6751 and EN 14214 respectively. In 2007, the biofuels consumption was relatively high, accounted for about 600 thousand kiloliters. According to the National Team for Biofuels Development, the level of consumption is projected to grow from the 2007 level to 9.84 million kiloliters by 2015, and grow further to 22.26 million kiloliters by 2025 .

As commonly known, biofuels can be produced from renewable raw materials such palm oil, sugarcane, corn, cassava, and jatropha. As a country with huge masses of land, Indonesia has large potential lands to grow those biofuels plantations. The National Committee join with other government agencies and ministries have proposed a special zone for biofuels plantations. According to the committee, the government has agreed to provide about 10,00o hectares of land in Java Island and another 100,000 hectares outside Java. In addition, to further support the national plan, the government will provide the infrastructures needed for biofuels projects. The government also covers the biofuels projects with the strong regulatory framework. There are at least sixteen government regulations -from Ministerial Decrees to Governmental Regulations and Laws-, which are enacted to support the national plan to further promoting the biofuels projects.

However, the government should notice that the development of biofuels not only provides positive externalities but also brings some negative externalities to the environment if not carefully managed. There will be a tradeoff between plant for fuels or foods. When the price bio-fuels plants such as sugarcane or palm oil is better than the price if it is sold as foods commodities, the farmers and the producers will have incentives to plant for fuels rather than for foods. If this is the case, there will create a shortage of food supply. In addition, as stated before, a large area of lands will be needed to plant biofuels plantations. As a result, there is much concern on the deforestation regarding the requirement of lands to grow biofuels plantations.

Once again, even though the plan on biofuels development will provide alternative energy for the future, the sustainability of the environment should be considered by the government. The regulations on biofuels should be accompanied by strict environmental protection policies. Hence, it is expected that the national plan on biofuels development will provide long-term sustainable development to Indonesia energy sector. 


\subsection{Hydro Energy}

The total capacity of the existing hydropower plants is only about 4200 MW; this capacity is far below the total hydropower potential, which is around 75,000 MW. There are at least two problems which hinder the development of hydropower plants. First, commonly, its locations are far away from the target customers. This has made hydropower potential is still being under-utilized. The long distance of hydropower generators fromthelocation will causehigh technical, and distribution losses. Second, the development of large hydropower plants will need high investment costs. It is well-known that to build a hydropower plant is not simply limited to installing a generator, but first, a dam needs to be built in order to maximize the potential of hydropower energy.

However, there are many hydropower potentials that are available at the small scale of about $500 \mathrm{MW}$ each. This is a great potential for micro-hydro power plants to be built. Therefore, microhydro power plant type is expected to play a greater role to supply electrify for the remote area surrounding the microhydro power potential. To stimulate the development of micro hydropower plants, the government should provide incentives to the investors, and even the government itself should be involved in the development process.

\subsection{Solar Energy}

As a country located in the equatorial zone, Indonesia has a relatively high potential of solar energy. The solar radiation potential is about $4.8 \mathrm{kWh} /$ $\mathrm{m} 2 /$ day; this amount will be enough to generate a solar home system power plant. The commonly used of the solar system is photovoltaic electricity system. Currently, the government has already installed 12 MW solar photovoltaic systems, with some of it - about 100,000 solar home systems (SHS) - being installed for the purposes of lighting, communication, television power, etc. For solar system development, the government has set a target to install another 30,000 SHS in the remote areas, especially in the Eastern part of Indonesia.

The GOI has provided the SHS equipment for free to the recipient households in the remote area. The government bought the equipment from private companies through a competitive bidding process. The intention to use the bidding process was to purchase the SHS equipment at a competitive price. However, learning from the international experience, this strategy seem has failed in the long-term due to lack of incentives for the households to maintain the SHS equipment. The alternative mechanism is to provide the SHS equipment through a rental system. The customers of SHS should pay a certain amount of charges to the operator for the costs of services and maintenance. However, the amount of charge should be regulated by the government, so that it will equal the marginal cost of providing electricity services using SHS. This strategy is expected to provide long-term electricity services to the households in the rural area.

\subsection{Wind Energy}

With the speed of wind for only about 3 to $5 \mathrm{~m} /$ second, Indonesia has only a small potential for wind energy. However, wind power is still worth to be exploited in some parts of Indonesia, especially in the coastal parts. Several wind power generators have been built in some areas such as Bali and Sulawesi. The existing wind power plants were installed for the purpose of promoting electricity in the remote areas. Currently, the MEMR has built several wind electricity power 
plants as pilot projects. During 2005 2007, the MEMR has built a wind power plant in Bali with capacity $6 \times 80 \mathrm{~kW}$ and another one in North Sulawesi with capacity $2 \times 80 \mathrm{~kW}$. In addition, the stateowned electricity company, PT. PLN also installed three units of wind power plants in Bali with capacity $85 \mathrm{~kW}$ each and it will be expanded by installing another 15 units throughout Bali. PT. PLN will also build some other wind power generators such as $3 \times 250 \mathrm{~kW}$ units in West Nusa Tenggara, $2 \times 100 \mathrm{~kW}$ units in East Nusa Tenggara, and a $300 \mathrm{~kW}$ wind project in West Java. Average investment costs to build a single wind power is estimated to around Rp. 30 million (USD 3250) per installed kW [15].

\section{The Economics of Renewable Energy in Indonesia}

In the Energy, Blueprint 2005-2025 stated that the MEMR intends to boost the share of renewable energy among the total energy supply from about $4 \%$ currently to $15 \%$ by 2025 . However, the Energy Blueprint is less articulate in discussing the economic viewpoint of energy. Indeed, theplan tofurther develop renewable energy should consider the economic perspective of promoting renewable energy so as to make plans comply with the market. Two problems currently exist regarding the economics of promoting renewable energy in Indonesia. First, the high subsidy for petroleum prices and electricity tariffs, and natural gas price ceiling. From the economic point of view, subsidy and price ceiling are inappropriate policies. The subsidy will cause low incentive for the consumers to conserve the use of fossil fuels, while price ceiling will prohibit natural gas price to achieve its economic value. In addition, the impact of low prices would cause more of the resource to be used in the earlier years.
As a result, consumption level in those years would be higher under subsidy and price control compare to the absence of them.

Historically, electricity power generation in Indonesia has been treated as a regulated monopoly. In Indonesia, power generation, distribution, and retail sectors are monopolized by State-owned Electricity Company (PT. PLN). This policy causes the electricity company to operate under its best performance since there is no competitor and incentive to be more efficient. In addition, the barriers to entry in Indonesia electricity market also make it difficult for more efficient producers and small-scale power generators to enter the market. The MEMR should consider deregulating the electricity market in order to force the electricity market to become more efficient and competitive.

Second, the government has not included negative externality costs of fossil fuels combustions to the price of fossil fuels. Without imposing negative externality costs to the price of fossil fuels, there will be a lack of incentives for the consumers to choose renewable energy as alternative sources of energy. Hence, a policy that imposes the negative externality costs of fossil fuels combustions to the prices of fuels is urgently needed. Alternatively, a policy that provides subsidies and incentives for research and development of renewable energy sources and technologies should be enacted.

Furthermore, there are two factors determine the development of renewable energy sources and technologies in the future. On the demand side, the rapid growing of fossil fuels demand could hinder the utilization of renewable energy. The current technologies that are widely used in Indonesia such as automobiles, power plants and industrial machinery mostly use fossil fuels as its 
energy sources. On the supply side, the supply of renewable energy sources is still limited, and its prices are still less competitive compared to fossil fuels prices. Therefore, the national plan to increase the utilization of renewable energy should be supported by an integrated energy policy on renewable energy and energy efficiency as well as market price signals.

\section{Conclusion and recommendation}

Based on the quantitative analysis, it is suggested that the development of renewable energy in Indonesia gives a positive impact to the economy. The economy in this regard represented by GDP and trade balance. The analysis in this study also shows that Indonesia has a great potential to improve its energy efficiency by adopting and employing renewable energy sources and technologies. Even though the current progress of renewable energy development is still insignificant, the outlook for renewable energy development is quite prospective. Hence, the effort to promote the development of renewable energy sources and technologies should be further supported by the GOI. To create such an economic of scales and achieve a significant market share, renewable energy sources and technologies need extra support in the form of subsidies, tax incentives, or R \& D support.

In order to promote further use and the invention of renewable energy sources and technologies in Indonesia, this study proposes an integrated renewable energy policy, energy market reform policy, and institutional policy.

\section{Acknowledgements}

The authors gratefully acknowledge the support from Planning and Foreign Cooperation Bureau at Ministry of
Energy and Mineral Resources of the Republic of Indonesia.

\section{References}

Abulfotuh, F., 2007. Energy efficiency and renewable technologies: the way to sustainable energy future. Desalination 209, 275-282

Geller et al., 2006. Policies for increasing energy efficiency: Thirty years of experience in OECD countries. Energy Policy 34 (2006) 556-573.

Stern, N., 2007. Stern Review: the Economics of Climate Change. Available at: http://www.hmtreasury.gov.uk/sternreview_ index.htm

REN21, Worldwatch, 2008. Renewables 2007 Global Status Report. Available at: http://www.ren21. net/pdf/RE2007_Global_Status_ Report.pdfS

EIA, 2007, International Data, Energy Information Administration, Official Energy Statistics of the U.S. Government. Available at: http:// www.eia.doe.gov/.

World Development Indicator 2009

EIA, 2009, International Data, Energy Information Administration, Official Energy Statistics of the U.S. Government. Available at: http:// www.eia.doe.gov/

Domac, J., Richards, K., Risovic, S., 2005. Socio-economic drivers in implementing bioenergy projects. Biomass and Bioenergy 28, 97-106

EIA, 2006, International Data, Energy Information Administration, Official Energy Statistics of the U.S. Government. Available at: http:// www.eia.doe.gov/

Deffeyes K. S., 2001. Hubbert's Peak: The Impending World Oil Shortage. Princeton, NJ: Princeton University Press, 2001. 
Campbell, C. J., Laherrère, J. H., 1998. The End of Cheap Oil. Scientific American

Tietenberg, T., and Lewis, L., 2009. Environmental \& Natural Resource Economics, 8th Edition, AddisonWesley Series in Economics, 2009

Taylor et al., 2007. Financing energy efficiency : lessons from Brazil, China, India, and beyond. Washington DC: World Bank
Pertamina, 2007, Indonesia geothermal proven reserves. Pertamina, Indonesia. Available at: http:// www.pertamina.com/

EIA, 2008, International Data, Energy Information Administration, Official Energy Statistics of the U.S. Government. Available at: http:// www.eia.doe.gov/ 